Н. М. Малюга

\title{
ПРО СУСПІЛЬНУ ПОТРЕБУ Й ПРАГМАТИЧНУ МЕТУ ДВОМОВНОГО УКРАЇНСЬКО-РОСІЙСЬКОГО ТА РОСІЙСЬКО-УКРАЇНСЬКОГО ПАРЕМІОЛОГІЧНОГО СЛОВНИКА
}

Малюга Н. М. Про суспільну потребу й прагматичну мету двомовного українськоросійського та російсько-українського пареміологічного словника.

У статті наголошено на потребі спеціальної лексикографічної праці, завданням якої є впорядкувати найбільш уживані прислів'я і приказки української та російської мов, описати значення і можливості використання в тексті, продемонструвати типові випадки варіювання в мовленні, окреслити типові ситуації, у яких вони побутують, виявити „фонову” культурно-історичну інформацію.

Ключові слова: паремія, прислів’я, приказка, російська мова, українська мова.

Малюга Н. Н. О социальной потребности и прагматической цели двуязычного украинско-русского и русско-украинского паремиологического словаря.

В статье сделан акцент на потребности специальной лексикографической работы, задание которой видится в упорядочивании наиболее частотных пословиц и поговорок украинского и русского языков, описывании значений и возможностей употребления в тексте, демонстрации типичных случаев варьирования в речи, типичных ситуаций, в которых они используются, выявлении „фоновой” культурно-исторической информации.

Ключевые слова: паремия, пословица, поговорка, украинский язык, русский язык.

Maluga N. M. About a society need and a pragmatic aim of bi-linguale UkrainianRussian and Russian-Ukrainian paremiological dictionaries.

There is a need of a special lexico-graphical study in this article. The task is regulating of the common use proverbs and sayings in Ukrainian and Russian languages, describing the meanings and abilities of using in the text, displaying of the typical cases of variation in speech, the typical situations, where they are used, revealing the „background” of the culturalhistorical information.

Key words: paremia, proverb, saying, Ukrainian language, Russian language.

У переліку труднощів тлумачної лексикографії на перше місце виходить виокремлення значень, акуратність тлумачень, стилістична кваліфікація одиниці загалом або їі конкретного значення, підбір ілюстрацій і т. ін. Як 
справедливо зауважує В. І. Бєликов, перед упорядником фразеологічного (у широкому сенсі) словника постає ще одна загальновідома проблема: упорядкування самих словникових статей. При цьому необхідно дотриматися балансу інтересів: адресат повинен легко знаходити в словнику потрібну інформацію, проте й упорядник хоче хоч якось відбити власний погляд на організацію фразеологічного (пареміологіческого) фонду. Про принципи устрою, компанування словника повідомляє передмова, але лише поодинокий читач згоден вчитися користуватися книгою і знайомитися 3 передмовою [1]. Крім того, „відсутність чітких критеріїв аналізу паремій, принципів відбору матеріалу, неврахування його специфіки й особливого статусу в мовній системі, співвідношення універсального й національного в різних типах паремій, зокрема в дослідженнях на матеріалі однієї мови, часом призводить до викривлення ïx результатів, суперечливих висновків при розгляді прислів 'їв і приказок навіть однієї тематичної групи чи блоку в працях різних авторів” [4, с. 35].

Розуміння образних висловлень, особливо нерідної мови, завжди наштовхується на різноманітні перешкоди, зокрема комунікативнопрагматичного, соціокультурного характеру. Прислів'я використовуються переважно з переносним значенням (у їхньому складі слова втрачають свою предметну співвіднесеність), відтак вони потребують тлумачення. Роз'яснення змісту таких одиниць необхідне носіям мови, а ще більше тим, хто намагається її опанувати. Як цілком справедливо зауважує К. І. Мізін, „тлумачні та фразеологічні словники, повнота укладання статей яких $\epsilon$ ще однією 3 досі нерозв'язаних проблем сучасного мовознавства, зокрема теорії фразеографії, значно відстають від дискурсивного мислення сучасного мовця" [5, с. 63-64].

Нині в українському мовному (більшою мірою двомовному) просторі 3 огляду на низку причин назріла нагальна потреба в перекладному пареміологічному словнику, у якому „поезія і мудрість, мистецтво місткого слова, здатність охопити одночасно і мале, і велике, влучність, проникливість життєвих характеристик" [2, с. 6] зазвучали б на два голоси.

Ураховуючи досвід наявних лексикографічних джерел як авторитетних, так i менш знаних, визначаємо завдання двомовного українськоросійського та російсько-українського пареміологічного словника: зібрати й упорядкувати найбільш уживані прислів'я і приказки української та російської мов, описати значення і можливості використання в тексті, продемонструвати типові випадки варіювання в мовленні, окреслити типові ситуації, у яких вони побутують, виявити „фонову” культурноісторичну інформацію, тобто подати смислову й ситуативну характеристику, а подекуди й контекстологічну (коли говорять, наприклад, у відповідь на запитання чи репліку).

Склад словника вважаємо за необхідне сформувати 3: а) активних у сучасній українській і російській мовах прислів'їв і приказок, широко 
представлених у художньому, публіцистичному й розмовно-побутовому стилях; б) ідеологічно застарілих одиниць, що зберігають конкретний соціально-історичний зміст; в) прислів'їв іншомовного походження, що набули продуктивності в українській і російській мовах; г) афоризмів, що відірвалися від свого літературного джерела.

Довідкова частина словникової статті може складатися 3 довідки історико-етимологічного характеру, вказівок на джерело походження (для запозичених одиниць), переліку форм прислів'їв і приказок, занесених до найбільш авторитетних збірок чи словників.

Словник розрахований на широке коло читачів, які можуть послуговуватися ним як довідковою літературою у процесі з'ясування смислу окремих прислів’їв і приказок; в освітній галузі, інформаційній сфері слугуватиме необхідним посібником для збагачення мовлення носіїв; матиме чималу користь у перекладацькій діяльності.

Від початку вивчення і збирання прислів’їв та приказок їхні публікації почали супроводжувати невеликими поясненнями: як розуміти смисл, до яких життєвих явищ їх відносити й т. ін. До цього часу ще йде пошук об'єктивної методики етимологічного аналізу прислів'їв: часто гонитва за історичними та етнографічними фактами перешкоджає строго мовній аргументації достовірності тієї чи тієї гіпотези [7, с. 6].

В основі внутрішньої форми пареміологічних одиниць будь-якої мови лежить образне світосприймання народу, що грунтується на метафоризованому осмисленні буття, традицій, звичаїв, обрядів, вірувань 3 урахуванням психоповедінкових архетипів. Цілком підтримуємо твердження 3. Г. Коцюби про те, що „паремійні фонди цікаві не лише як результат акумулювання та систематизації соціокультурного досвіду, але й соціальної адаптації найрізноманітніших виявів конвенційних норм культурного регулювання, що виявляються на ментальному рівні: панівної моралі, цінностей та оцінних критеріїв, норм етикету, звичаїв, обрядів, побутової ерудиції в соціально-гуманітарних і природничо-наукових знаннях" [4, с. 34].

У межах досліджуваних переміологічних одиниць простежується симбіоз лінгвальних і екстралінгвальних універсальних чинників, які акумулюються головним чином образами-еталонами. Виокремлюємо співставлювані пареміологічні одиниці, ізоморфність плану змісту та вираження яких у різних мовах свідчить про універсальність семантичного підгрунтя світу. Пор., наприклад, укр. I в цчигана душа не погана та рос. И у цььгана душа не погана; укр. На вербі грушки не родяться та рос. Не родит верба груши; укр. Ні від суми, ні від тюрми не зарікайся та рос. Ни от сумы, ни от тюрьмы не отрекайся. Таке зіставлення цілком підтверджує висновок 3. Г. Коцюби про те, що „будьяке дослідження, що грунтується на аналізі прислів”ів і приказок однієї чи кількох мов, <..> дає змогу простежити як національну специфіку 
світогляду творців паремійних фондів мов, так i загальнолюдські особливості мислення й універсальну здатність людини до образного передавання уявлень про світ" [4, с. 47].

Далеко не всі прислів'я вимагають історико-етимологічного та етнографічного коментарю: якщо образ зрозумілий читачеві на основі його власного мовленнєвого досвіду, то коментарі зайві. Наприклад: 1) рос. Что у кого болит, тот о том и говорит. Використовується в ситуації, коли будь-хто в розмові постійно повертається до того, що його тривожить, хвилює. Пор. укр. Що в кого болить, той про те й гомонить (говорить); Що кому рупить, той про те й лупить; Що кому треба, той про те й теребить; Що кому требить, той те й теребить; Де болить, там і торкнеш; Де (де в кого) не свербить, там ся не чухає; Що не свербить, то не кортить; У кого болить, той кричить; Де свербить, там і почухаєш, де болить, там і торкнеш; 2) рос. Видима беда, что у старого жена молода. Використовується в ситуації, коли хочуть попередити про наслідки нерівного шлюбу між чоловіком у літах та молодою жінкою або констатувати сімейні негаразди, що, 3 погляду інших людей, $є$ цілком закономірними й очікуваними. Пор. укр. Біда, коли в старого жінка молода; Молода жінка старому трутизна; Де муж старий, а жінка молода, там рідко згода; Бджола мед носить не для себе, вівия шерсть носить не для себе, старий жениться не для себе; Не (чи, хіба) надовго старий жениться! [хоч сам згине, хоч жінка покине; або вмре, або скрутиться].

Якщо власні імена уособлюють певні якості, особливості психофізіологічного стану, соціального статусу людей, вони „закріплюються в народній свідомості як загальні, що втрачають за таких умов первинні властивості індивідуального найменування" [3, с. 167], відтак „утрата зв'язків із денотативним об'єктом та розвиток вторинних символічних співзначень у мовленні дає можливість функціонувати онімам як субститутам соціально-оцінних апелятивів або узагальнено-вказівних знаків з абстрактною семантикою" [6, с. 7]: У мене Хома - й добра нема (пор. рос. Был у меня муж Иван - не приведи Бог и вам); Який Сава, така й слава (пор. рос. Каков Дёма, таково у него и дома); По Савці свитка (пор. рос. По Ивашке [u] рубашка; По Сеньке [u] шапка [по Ерёме колпак (кафтан)]), Бідному Савці нема долі ні на печі, ні на лавці: на печі печуть, на лавиі січуть; На бідного Хому і дерево падає (пор. рос. Горькому Кузеньке горькая и песенка; Нашему Ивану нигде нет талану); Пішов Тарас за лозами (пор. рос. Ушел Вавило по мотовило, да, видно, лесом задавило); Ти йому про Тараса, а він тобі півтораста; Хто про Хому, а він про Ярему (пор. рос. Я про Фому, а он про Ерему); Катерина та Василь посварилися за кисіль; Катерина Василю не давала киселю; Катерина та Дем'ян посварилися за бур'ян; Катерина Дем'яну не попустить бур'яну (пор. рос. Не сошлось Онохино пиво с Нестеровым); Блеяй, пане Свириде, 
побачим, щзо з того вийде; Говорив Мирон рябої кобили сон; Говори, Климе, нехай твоє не гине; Мели, Денисе, погода тягне; Мели, Іване, доки (поки) вітру стане (пор. рос. Мели, Емеля, твоя неделя); Забагатів Кіндрат - забув, де його брат (пор. рос. Портит Ивашку белая рубашка); Не зівай, Химко, на те ярмарок (пор. рос. Прищуривай, Агашка, на левый глаз); Радуйся, Хвесько, кіт сало несе: радуйся вельми, бо вже перед дверми (пор. рос. Радуйся, Кирюшка, будет у бабушки пирушка). На розвиток апелятивного співзначення та виникнення конотацій, як указує Н. М. Пасік, „має вплив цілий ряд факторів: тип ономастичної основи $<\ldots>$, реальність або ірреальність денотата імені, рівень відомості оніма та його денотата мовцям, частотність уживання оніма, симпатія або антипатія мовного загалу до нього, фонетичний чинник, етимологія, структурноорганізаційні характеристики власної назви (здатність римуватися, бути співзвучною зі словами-апелятивами), традиції, звичаї, зміни світогляду, прагнення до експресіі” [6, с.7].

В українській, як і російській антропоніміці, 3 власними іменами традиційно пов'язуються певні риси характеру, вдачі, психічні, фізіологічні властивості. Традиційно продуктивні українські імена перебрали на себе такі характеристики: Солоха - неспритна, Ганна, Хвеська, Химко - недоумкуваті, Карпо - простакуватий, Гриць - при відсутності соціального статусу має завищену самооцінку. На думку О. Є. Фролової, яку ми поділяємо, „антропонім у прислів 'ї поєднується 3 екстралінгвістичною ситуацією і стає іiі знаком" [9, с. 43]. Імплікування енциклопедичної інформації, пов'язаної 3 денотатами, спричинило створення містких символічних співзначень імен, вони виконують функцію типізатора: Голодній Гапці хліб на гадиі; Це тая Солоха, що кури полоха; Не для Гриця паляниця; Без нашого Гриця вода не освятиться; Зібрав Бог пару - Карпа й Хвеську; Який дідько з Химка, така його жінка.

Народне образне уявлення може зазнавати змін і перетворень, але залишається основотворчим компонентом пареміологічної одиниці, структурування самої національно орієнтованої пареміології, а по тому засобом формування національно-культурної картини світу. Наприклад: На городі бузина, а в Києві дядько; Далеко п'яному до Києва; По дурнів нічого в Київ їхати - вони й тут є; Дурень до Києва, дурень $i$ з Києва; Дурний і в Києві не купить розуму; Язик до Києва доведе; Добувся, як швед під Полтавою; Добувся, як під Очаковом; Хто любить піч, тому ворог Січ; Ніс так ніс, як через Дніпро міст; Подарунько за Дніпром без штанів ходить (пор. рос. Москва не сразу (не вдруг) строилась; Москва от копеечной свечки (свечи) сгорела (загорелась); Москва слезам не верит; У нас на Рязани и свинья в сарафане; Ума палата, а глупости Саратовская степь; Справится дело и без Новгорода). Усі наведені паремії мають специфічно національний характер, до їх складу входять 
оніми, які викликають уявлення про Україну чи Росію відповідно. Такі одиниці генетично споріднених мов фіксують різні соціокультурні стереотипи.

Усвідомлення внутрішньої форми, образної мотивації українських i російських прислів’ів і приказок пов'язується з можливими асоціаціями, зумовленими знанням традиційної образності, буттям українського i російського народу, тобто пресупозитивним фоновим змістом. Структура таких пресупозицій досить різна й строката; ïi сигналами служить компонентний набір співставлюваних одиниць.

Прислів'я і приказки, що містять назви предметів побуту (передусім селянського), їжі, засвідчують народну образність, побудовану на власне українських чи російських світоглядних принципах. Так, залучення до багатьох національно мотивованих українських паремій компонентів на зразок сало, паляниця, борщ, хата тощо, є процесами непрямої номінації, викликаної творчою фантазією народу: $\epsilon$ сало, та не можу (не можна) дістати [високо висить]; Їв би паляниці, та зубів нема; (рос. Видит кот (собака) молоко, да рыло коротко); Не для пса ковбаса, не для кицьки сало; Не для Гриця паляниця; С сало, та не для кота; (рос. [Eсть-то] есть, да не про вашу честь); Який пан, такий крам (такий і жсппан); Яка хатка, така й паніматка; Яка пшениця, така й паляниця; Яка хата, такий тин, який батько, такий син (рос. Каков едет, таков и погоняет); Де багато господинь, там хата не[за]метена; Де велика рада, там рідкий борш; Два кухарі - лихий борщ (рос. У семи нянек дитя без глазу; У семи пастухов не стадо); Унадився (повадився, занадився) кухоль по воду ходити, поки йому вухо (вушка) не відірвали (не одламали); Пішов глечик по воду та й голову (голівку) там положив (та й пропав там з головою); Повадиться глечик по воду ходить, там йому й голівку положить; До часу глек (глечик, дзбан) воду носить; Доти (поти) дзбан (глек) воду носить, доки (поки) вухо увірветься (рос. До поры и кувшин по воду ходит; Повадился кувшин по воду ходить - там ему и голову сломить). Щоб розкрити значення паремії, необхідно ремотивувати іiі внутрішню форму, тобто розкодувати сконденсовану в ній семіотичну лінгвальну й екстралінгвальну інформацію. Українська переміологія відображає натурфілософські погляди, символіку українського народу, побудовану на персоніфікаціях, своєрідному образному сприйманні картини світу. У сучасних лінгвістичних студіях пошуки образних утілень народних уявлень про світ і людину в ньому, закодованих у пареміях, здійснюються „через методику реконструкції гештальтних метафор, результати яких підтверджують думку про те, що концептуальне осмислення категорій культури знаходить своє втілення в системі образів, які є своєрідною нішею для кумуляції світогляду народу" [4, с. 44].

Усебічне вивчення мовних універсалій сприяє виявленню універсальних підвалин людського мислення та дозволяє віднайти 
унікальні одиниці певної мови, які є маркерами етносвідомості народу. Як пише К. І. Мізін, „дослідження мовних одиниць на основі опозиції „унікалії - універсалії дозволяє заповнити лакуни при укладанні дво- чи багатомовних фразеологічних або ідеографічних словників" [5, с. 65]. Визначення чинників еквівалентності сприяє прогнозуванню наявності відповідників тієї чи тієї усталеної одиниці, чому допомагає виявлення універсальних характеристик і специфічних особливостей пареміологічних фондів зіставлюваних мов. Крім цього, унікалії репрезентують увесь колорит лінгвокраїнознавчої інформації, що робить їх цінним лінгводидактичним матеріалом. Закономірно постає питання: чи може бути семантика унікальною в принципі? На це питання К. І. Мізін дає заперечну відповідь, „оскільки за допомогою семної комбінаторики можна передати будь-яке значення" [5, с. 64]. Більшість перекладознавців заперечує існування феномену неперекладності.

Навіть при спільному джерелі виникнення пареміологічних одиниць (Біблія, твори художньої літератури тощо), не кажучи вже про випадки їх паралельного формування в різних лінгвокультурах на основі ізоморфності об'єктивного світу, семантика таких універсальних одиниць зазнає етнокультурних „корекцій”. Етнокультурні зрушення „провокують” зміщення образів-еталонів у різних мовах. Пор., наприклад, укр. Брат любить сестру багату, а чоловік жінку здорову (хорошу); Сестра любить, коли брат багатий; Тоді любить і сват, коли добре має брат; а коли бідний, то забуде $i$ брат рідний; При добрій годині $i$ куми побратими, а при лихій нема і родини; В нещастю нема ні брата, ні свата та рос. Муж любит жену богатую, а тёщу тороватую; Мужс любит жсену здоровую (красивую), а брат сестру богатую. У коло найближчих осіб, на кого можна напевне розраховувати, від кого сподіваються підтримки (фізичної, матеріальної) у скрутну хвилину, у російській етнокультурній свідомості входять люди, пов'язані шлюбними стосунками (муж - жена), кровними зв'язками (брат - сестра), родинними опосередкованими зв'язками (теща); у свідомості українця це коло ширше: родина загалом, побратим, кум, сват. Так, наприклад, побратимство у XV - XVIII ст. було одним 3 улюблених звичаїв українських козаків, часто побратимів благословляв священик. Якщо ж порівняти укр. прислів'я На те ициган матку б' $\epsilon$, щоб його жінка боялась; Кішку б'ють, а невістці замітку дають та рос. Бей своӥх - чужие будут бояться, розходження в розумінні значення „свій - чужий”, а також родинної ієрархії та цінностей виявиться глибшим.

В українському фольклорі образ Бога невіддільний від образу селянина. Бог у біблійному значенні - творець усього сущого, що керує світом і вчинками людей; в образному вживанні - носій найвищих людських ідеалів, моральної довершеності, утілення ідеї людського щастя, справедливості. Символічне значення слова сягає корінням у давню 
слов'янську міфотворчість, де божество - це і доля, щастя [3, с. 71]. Слово-символ Бог містить компоненти „усемогутність”, „невідворотність”, „справедливість”, „усеохопленість”, „усебачення”, ,доля”, „кара”.

Утрачаючи безпосередній зв'язок із біблійно-богословським осмисленням поняття, частина паремій із словом Бог набуває народнорозмовного, зниженого характеру; за таких умов оцінні характеристики переміщуються в площину нульової відмітки; інколи виникає відтінок спрощеного, власне побутового бачення образу, елемент гумористичного «запанібратства» [3, с. 72]. Наприклад: Кинь мене, Боже, де мене не треба! (пор. рос. Наш пострел везде поспел).

Переосмислюючись в українському мовному оточенні під впливом етнолінгвістичних чинників, способу життя, традицій, старовинних вірувань, біблійні символічні назви (а також назви релігійних свят і їх атрибутів, назви духовних наставників, осередків та угруповань віруючих, дій, мотивованих біблеїзмами тощо) наближалися до повсякденного побутового, уснорозмовного, фольклорного вживання. Наприклад: Де ще у Бога теля, а він з довбнею вже носиться!; Де щуе у Бога літо, а він вже (а він о Різдві) косу клепа; Де той у Бога Великдень, а він уже із крашанками! (уже й з пасками); Хрестять люди, хоч ще не вродило; Те хрести, що родиться (рос. Медведь в лесу, а шкура продана); Забажати (захотіти) мерзлого в петрівку (рос. Захотел молочка от бычка); Який піп, така його й парафія (такі ци парафіяни); Який піп, таке й благословення; Добрий nin, добре й благословення (рос. Каков поп, таков и приход; Каков пастырь, таковы и овцьь); На Миколи та ци ніколи (рос. После дождика (дождичка) в четверг); Душа грішить, а тіло покутує (рос. Нога споткнётся, а голове достаётся; Душа согрешила, а спина виновата; Ручки делают, а спинка отвечает); Сама себе раба б'є, щзо нечисто жито жне (рос. Сам на себя в кнут узлов навязал); Від смерті ані відхреститися, ані відмолитися (рос. От смерти не откупишься).

Свого часу турецький мандрівник Ельвія Челеві, що відвідав Україну 1657 року, засвідчив величезне багатство й виражальні можливості української мови, але лайливих слів нарахував у ній лише чотири, а саме: чорт, дідько, свиня $i$ собака. Стійкий вираз «лаятися по-чорному» пов'язаний $з$ уживанням під час побудови лайливих конструкцій слова «чорт» і похідних від нього - саме це слово для давніх українців було найстрашнішою лайкою. Наприклад: Чорт скорих бере; Поспішних чорт хапає (рос. Быстрая вошка первая на гребешок попадает); Бодай старого чорт учив! (рос. Старого учить - что мёртвого лечить); Сивини в голову, а чорт в бороду; Сивина в бороду, а біс у ребро; Чоловік старіє, а чортяка (чорт) під бік; I в старім пєиу часом чорт палає; I в старій печі дідько топить (рос. Старость от соблазна не затулье); Чорт (дідько) сім (сімдесят) пар постолів стоптав, поки їх докупи зібрав (сходив, поки докупи зніс); Чорт тридияять пар лаптів стоптав, поки піп таку пару 
підобрав; Хоч чорт лапті подрав, та докупи зібрав; Не мало чорт ходаків сходив, заким їх позносив; Який дідько з Химка, така його жінка; Який чорт з Шишка, така його й жінка (рос. Хороша парочка, как баран да ярочка) і навпаки Чого на світі не буває (рос. Чем чёрт не шутит). Як свідчить ілюстративний матеріал, українські паремії тяжіють до зловживання згадуванням нечистого. Чорт, диявол уособлюють підлість, підступність, зрадництво, злобу тощо. Усе гірше, що оточує людину, несе ій страждання, нещастя, загибель, пов'язане з цими образами. У широкому абстрактному плані диявол (сатана) виразник ідеї конечності всього сущого [3, с. 76].

Українські паремії відображають схильність українців до різкості в оцінках тих явищ, які, з погляду народу, заслуговують осуду. Продуктивне вживання зневажливої форми середнього роду субстантивованих прикметників та займенників в українсько-російському міжмовному зіставленні $\epsilon$ промовистою характеристикою специфіки українського світогляду. Наприклад: Голе, як миша, а гостре, як бритва (пор. рос. Гол, как сокол, а остёр, как бритва); Голе, аж ребра світяться; Голе, аж крізь ребра видно (пор. рос. Такая голь, что парня нечем высечь); Завзяте як перець, покіль не вийде на гер[е]иь (пор. рос. Молодец на (против, среди) овеи, а на (против, среди) молодиа [и] сам овиа); Яке маленьке, а не несе ложки за вухо ( пор. рос. И заика ложку мимо ушей не проносит); Яке поӥхало, таке повернуло (пор. рос. Каков едет, таков и погоняет); Яке в колиску, таке в могилку (пор. рос. Каков в кольбельку, таков и в могилку).

Економічний розрахунок при виборі шлюбної пари відігравав не останню роль, хоч, безперечно, працьовитість, доброта і врода обраниці теж бралися до уваги. Наприклад: Хоч жінка свинка, так грошей скринька; Жінка хоч корова, аби здорова (пор. рос. Будь жена хоть коза, лишь бы золотые рога). Як нам видається, російський відповідник дещо змінює акценти: роги традиційно в шлюбі пов'язують із подружньою невірністю, але на ,золоті роги” можна погодитися з певного розрахунку.

Розбіжності в образності тотожних за смислом російських та українських паремій С. Таглін пояснює відмінністю образних профілів українців і росіян, за якими російський етнос схильний віддавати перевагу образам, пов'язаним із людиною, а українці - образам, пов'язаним із домашнім господарством [8, с. 26]. Пор., наприклад, укр. $У$ гарного господаря $i$ мишка господиня; $У$ доброго хазяїна $i$ кішка господиня ( $і$ свинка господинька) та рос. У умного мужа и глупая жена досужа. Однак це не говорить про те, що образи українських паремій не мають антропоцентричного вектора, див., наприклад, прислів'я із синонімічним значенням: За добрим чоловіком $і$ чулинда жінка [а за дурним і попівна рабинька].

В обох зіставлюваних мовах представлені співвідносні паремії, які відображають усвідомлення диспропорції між чеснотами чоловіка та його 
роллю в житті жінки, схильність суспільства поблажливо ставитися до вад чоловіків і несхвально, суворо - до самотніх (з різних причин) жінок: пор. укр. Сякий-такий, аби був - аби хліба роздобув; Чоловік, як ворона, та все ж мені оборона; Хоч поганий тин, та затишно за ним та рос. Худ мой Устим, да лучше с ним.

Загалом українські й російські прислів'я передають схоже ставлення до дружини, однакове розуміння взятого на себе обов'язку перед нею. Такі паремії в зіставлюваних мовах побудовані за однією моделлю. Це й не дивно, адже, як зауважує 3. Г. Коцюба, „при закономірній варіативності образів спільних для всіх культур класів значна частина образів у пареміях народів, які проживають у подібних географічних і соціальних умовах, усе ж буде спільною, що зумовлює як творення прислів'їв і приказок на однаковій образній основі, так і їх безперешкодне проникнення з мови в мову народів-сусідів, про що свідчить існування сотень однообразних паремій у різних мовах європейського провербіального простору" [4, с. 47]. Пор. укр. Жінка не черевик: із ноги не скинеш та рос. Жена не сапог (не лапоть), с ноги не скинешь; Жена не рукавица, с руки не сбросишь (за пояс не заткнешь); Жена не гусли: поиграв, на стенку не повесишь; Жена не седло: со спины не сымешь). Однак саме розуміння важливого рішення одружитися має суттєві відмінності. Так, українці беруть за основу темпоральну ознаку - це не на якийсь час, а довіку; натомість росіяни відходять від сприйняття „на вагу” - це не так легко, як може здатися. Пор. укр. Заміж вийти - не дощову годину пересидіти (перестояти); Зашлюбитись - не дощик переждати (перечекати) та рос. Жениться - не лапоть надеть.

Українські прислів’я фіксують прагматичну вдачу українців, потребу бути ситими, культ їжі. Так, у ситуації, коли говорять про те, чого не можна відкладати, оскільки доки наступить, відбудеться щось довгоочікуване, бажане, уже відпаде в ньому потреба, буде пізно; або коли не сподіваються скоро отримати обіцяне, дочекатися здійснення чогось, у російській мові використовують прислів'я Поколе солнышко взойдет, роса выест глаза; Пока (покуда) солнце взойдет, роса глаза (очи) выест; Улита eдет, когда-то будет. Із цим же значенням в українській мові, крім співвідносних Поки (доки, заким) сонще зійде, роса очі виїсть; Поки найде, то й сонще зайде, представлені паремії, більшою мірою орієнтовані на добробут: Поки бабуся спече книші, у дідуся не буде душі; Надіявся дід на обід, та без вечері ліг спати; Поки багатий стухне, то убогий опухне; Поки гладкий схудне, то худий здохне; Чекай, собачко, здохне конячка матимеш м'ясо; Його по смерть добре посилати, то нажитися можна; Поки хвалько нахвалиться, будько набудеться. Невипадково образна структура паремій як джерело пізнання етнічних особливостей свідомості $\epsilon$ об'єктом зацікавлення не лише лінгвістів, а й етнопсихологів, які вбачають у пареміях знаряддя етнопсихогенезу. 
У передмові до „Словаря русских пословиц и поговорок” В. П. Анікін пише: „Прислів'я рідко бувають спокійними. Вони, як і люди, що їх створили, гніваються, сумують, сміються, глузують, веселяться, плачуть, охають, стогнуть, кричать, пустують, балагурять, пугають, застерігають, учать, обурюються - словом, у них стільки ж почуттів, скільки їх в народі творці прислів“їв” [2, с. 4]. По приклади експресивних одиниць далеко ходити не треба: пор. укр. Дулю дати під ніс; Дулю з '̈э;; А дзуськи, холодию їсти!; Дати йому куку в руку та рос. Вот тебе кукиш, чего хочеш, того и купишь); Плугач оре і в прачі рветься, а панське черево отак аж дметься! (пор. рос. Овиь и мрут, и ягнятся, а пастухи всё жирятся. За кожним із прислів'їв стоїть авторитет поколінь, які їх склали, вони постулюють універсальні типи суспільної поведінки та їх потенційну оцінку.

Якщо варіативність лексичної одиниці - поодинокий виняток, у пареміологічному фонді це норма. Варіантність прислів'їв і приказок викликана низкою причин. В одних випадках нові варіанти постають унаслідок заміни одного якогось слова іншим, переважно подібним за змістом, в інших випадках той чи той варіант з'являється за рахунок формальної чи словотвірної видозміни одного з компонентів, нарешті, новий варіант може утворитися в результаті лексико-граматичної перебудови прислів”їв та приказок. Наприклад: 1) Ще й риби не піймали, а вже заходилися юшку варити; Шкура вже продана, а ведмідь у лісі (Шкуру вже продано, а ведмідь ще в лісі); Ще вовка не вбили, а шкуру продають; Журавель у небі, а ти йому вже иіну визначив; Де ще те теля, а він уже з довбнею бігає; Теля де, а він уже із довбнею бігає (грає); Іще теля в пузі, а він уже із довбнею; Лоша в гузі, а вже обротьки плетуть; Де ще твоє порося, а ти з довбнею носишся (а він з довбнею носиться); Коли ще [та] косовиия, а ти вже по сіно їдеш (а ми вже сіно возимо) (пор. рос. Медведь в лесу, а шкура продана; Медведя не убил, а шкуру запродал; Не убил медведя, шкуры не продавай); 2) Бачили очі, щзо купували, - їжте, хоч повилазьте; Купили хріну - треба з'їсти!; Плачте, очі, хоч повилазьте: бачили, що купували, - грошам не пропадати (пор. рос. Назвался груздём (грибом) - полезай в кузов); 3) Коростяве порося дарма чесати; Щербатого горшка ніколи не поправиш (пор. рос. Старого пса к иепи не приучишь); 4) 3 лежі не справиш одежі, а з спання не купиш коня; Лежаний хліб не ситить; Якби все вовк лежав, то вже б досі $і$ здох (пор. рос. Под лежсч(ий) камень $[u]$ вода не течёт.

Від варіантності суттєво відрізняється явище факультативності, яке характеризується тим, що прислів'я чи приказка функціонує в мові в повному чи неповному складі. Факультативність поширюється на окремі слова або на всю останню частину названих пареміологічних одиниць. Факультативність не впливає на категоріальну характеристику прислів ”їв і приказок. У явищах варіантності й факультативності виявляється специфіка форми, зовнішнього вираження описуваних одиниць. 
Наприклад, укр.: Згадала баба дівера [що замолоду діяла]; Не роззявляй рота, бо сорока влетить [i висреться, то так погано буде - nху!]; Навпростець тільки ворони літають [а люди по дорозі ходять]; рос.: Ихочется и колется [и матушка не велит]; Не хвались, идучи (едучи) на рать [а хвались, идучи (едучи) с рати].

Досить часто запам'ятовування прислів'їв полегшується різними співзвуччями, рифмами, ритмікою: Ой, мати, хочу їсти, та боюся в погріб лізти; та боюся, щеб не впала, щчоб капуста не пропала (пор. рос. Хочется пирожок съесть, да не хочется в подполье лезть); Коза з вовком тягалася: тільки шкурка зосталася [тільки паністара зосталася, та ще хвіст, та язик: простяглась, та й лежить] (пор. рос. Кобыла с волком мирилась да домой не вкоротилась); Язиком мели, а руку держи (а руки при собі держи); Язиком що хоч як тіпай, а рукам волі не давай; Язиком що хоч кажи, а руки при собі держи; Язиком клепай, а руки при собі тримай; Дай рукам волю, то сам підеш у неволю (пор. рос. Языком мели (болтай), а рукам воли не давай). Продуктивність такого прийому активізації прислів 'їв досить висока в обох мовах.

Отже, різне наповнення паремій зумовлене відмінностями в мовних картинах світу лінгвосоціумів. Паремії репрезентують увесь колорит лінгвокультурної інформації, що робить їх цінним лінгводидактичним матеріалом. Зіставний аспект вивчення переміологічних одиниць, образиеталони яких є згустком етнокультурної інформації певного етносу, сприяє розкодуванню такої інформації та виявленню специфічних етнокультурних і ментальних рис цього етносу.

Перспективу пропонованого дослідження вбачаємо в зосередженні наукової думки на проблемі упорядкування найбільш уживаних співвідносних прислів”їв і приказок української та російської мов, окресленні типових ситуацій, у яких вони побутують, виявленні закодованої в пареміях культурно-історичної інформації.

\section{Література}

1. Беликов В. И. Паремии как объект лексикографии / Режим доступу: www.dialog-21.ru/dialog2008/materials/html/7.htm

2. Жуков В. П. Словарь русских пословиц и поговорок / Влас Платонович Жуков. - М. : Советская энциклопедия, 1966. - 535 с.

3. Кононенко В. І. Символи української мови / Віталій Іванович Кононенко. Івано-Франківськ: Плай, 1996. - 272 с.

4. Коцюба 3. Г. Паремії як об'єкт етнолінгвопсихологічного дослідження / 3. Г. Коцюба. - Мовознавсво. - 2009. - №2. - С. 34-47.

5. Мізін К. І. Системні маркери компаративної фразеології крізь призму зіставлення (на матеріалі англійської, німецької, української та російської мов) // К. І. Мізін. - Мовознавство - 2009. - №5. - С. 60-70.

6. Пасік Н. М. Власні назви в українській фразеології і пареміології : автореф. дис. на здобуття наук. ступеня канд. філол. наук: спец. 10.02.01 - українська мова / Н. М. Пасік // Інститут української мови НАН України. - К., 2000. - 18 с. 
7. Словарь русских пословиц : ок. 1000 единиц / В. М. Мокиенко, Ю. А. Ермолаева, А. А. Зайнульдинов и др. ; под ред. В. М. Мокиенко. - М. : Астрель : АСТ, 2008. - 381, [3] с.

8. Таглін С. Про народні паремії, національну свідомість та „малоросіянство” як етнопсихологічний феномен / Сергій Таглін // Збірник Харківського історикофілологічного товариства. - Х. : Око, 1994. - Т. 3. - С. 21-28.

9. Фролова О. Е. Пословица: ситуативность, синтаксис, референція / О. Е. Фролова // Вестник Моск. ун-та. Серия 9. Филология. - 2007. - №3. - С. 31-46.

Стаття надійшла до редакиї 27.09.2010 p. 